\title{
Orchard Laborer Dies when Crushed Between a Motor Grader and Semi-Truck in Washington State
}
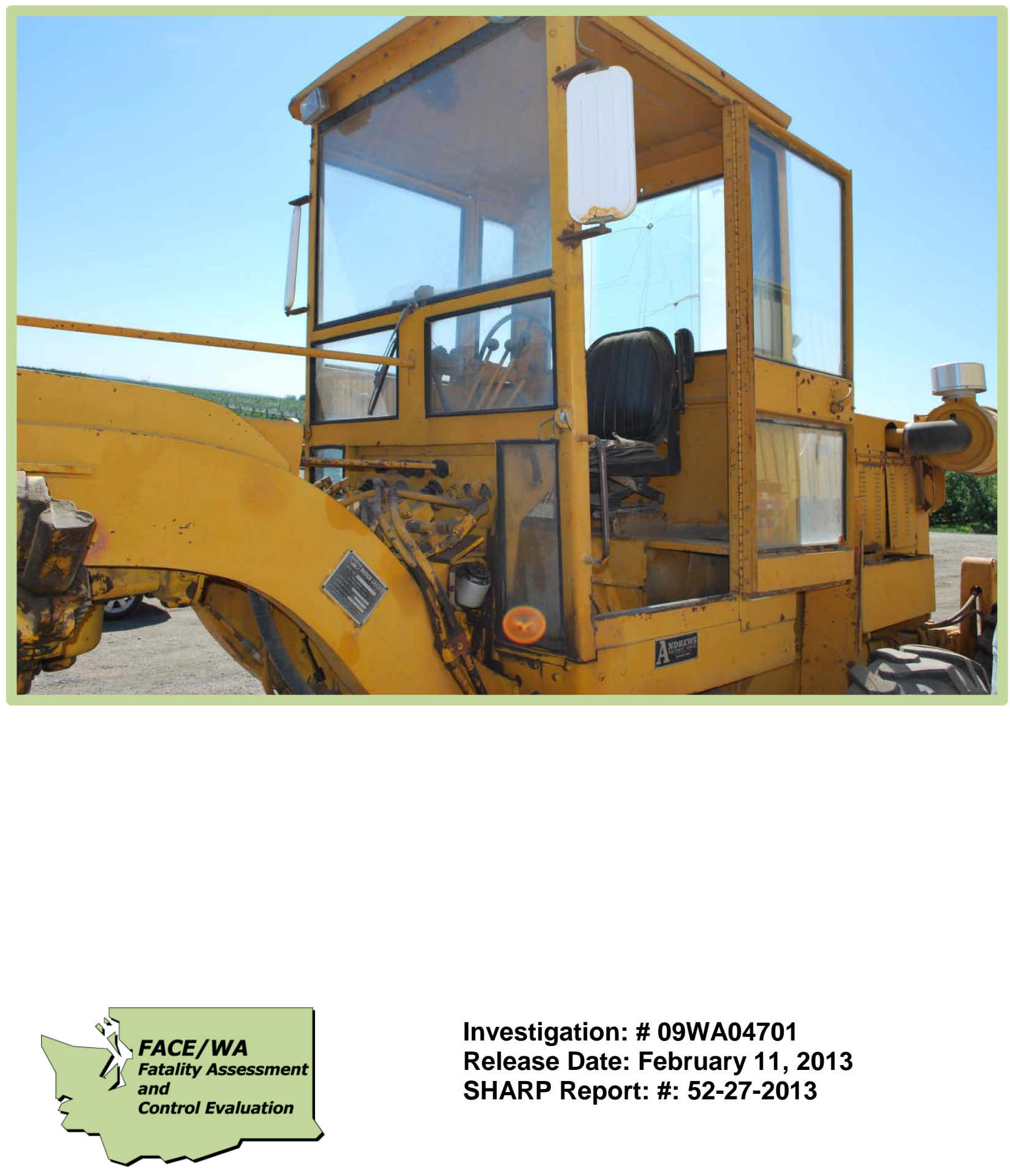

Investigation: \# 09WA04701

Release Date: February 11, 2013

SHARP Report: \#: 52-27-2013 
TABLE OF CONTENTS

Contents

Page

DEFINITIONS

3

SUMMARY

4

RECOMMENDATIONS

4

INTRODUCTION 4

EMPLOYER

EMPLOYER WORK ORGANIZATION

EMPLOYER SAFETY TRAINING PROGRAM 6

WORKER

SEMI-TRUCK DRIVER

OPERATOR OF MOTOR GRADER $\quad 7$

ORCHARD AND GRAVEL ROAD

SEMI-TRUCK AND FLAT BED TRAILER $\quad 8$

MOTOR GRADER 9

MOTOR GRADER BRAKES 10

INVESTIGATION

CONTRIBUTING FACTORS 12

CAUSE OF DEATH 12

RECOMMENDATIONS AND DISCUSSION 13

ACKNOWLEDGEMENTS 16

APPENDIX A: DIAGRAMS

APPENDIX B: JON HAZARD ANALYSIS TEMPLATE 19

REFERENCES $\quad 20$

INVESTIGATOR INFORMATION

FACE PROGRAM INFORMATION 21 
DEFINITIONS:

$\begin{array}{ll}\text { ANSI } & \text { American National Standards Institute } \\ \text { APP } & \text { Accident Prevention Program } \\ \text { ATV } & \text { All-Terrain Vehicle } \\ \text { DOSH } & \text { Division of Occupational Safety and Health } \\ \text { EMS } & \text { Emergency Medical Services } \\ \text { FACE } & \text { Fatality Assessment and Control Evaluation } \\ \text { JHA } & \text { Job Hazard Analysis } \\ \text { LBS } & \text { Pounds } \\ \text { NIOSH } & \text { National Institute for Occupational Safety and Health } \\ \text { SHARP } & \text { Safety and Health Assessment and Research for Prevention } \\ \text { SOP } & \text { Standard Operating Procedure } \\ \text { WA } & \text { Washington State }\end{array}$




\section{SUMMARY}

On September 27, 2009, a 38-year-old orchard worker was fatally injured when he was crushed between a motor grader and a semi-truck with a trailer. The semi-truck, which was at the orchard to pick up apple bins, was unable to maintain traction and got stuck while attempting to travel up a gravel orchard road with a 6-7\% grade. The worker and the semi-truck driver were attempting to tow the stuck semi-truck with the assistance of a motor grader operator.

The operator was reversing the motor grader downhill into position so the worker could attach the chain from the front of the semi-truck to the rear of the motor grader. According to the operator of the motor grader, he attempted to use the brakes about 40 feet uphill from the semi-truck but they failed, causing the motor grader to collide with the front of the semi-truck.

According to witnesses, the motor grader momentarily stopped about seven feet from the semi-truck, and then suddenly moved backwards crushing the worker and semitruck driver between the two vehicles. Emergency Medical Services (EMS) was contacted and the worker and truck driver were transported to the hospital. Approximately 1 hour after the incident the worker died.

To prevent similar incidences the Washington State Fatality and Control Evaluation Team (FACE) recommends:

1. Employers should implement and enforce the use of job hazard analysis (JHA) tools and techniques to identify and eliminate hazards.

2. Employers should create and enforce comprehensive standard operating procedures (SPOs) for towing vehicles.

3. Employers should ensure that all heavy mobile machinery is equipped with functioning safety systems and alarms.

4. All operators of heavy machinery should perform a safety inspection before operating machinery. Inspections should include functional testing of safety devices.

Designers and manufacturers of motor graders should:

5. Design and manufacture motor graders with safety features that notify the operator that there are workers near or in the path of the motor grader. 


\section{INTRODUCTION}

On September 28, 2009, Washington State Fatality Assessment and Control Evaluation program (FACE) was notified by Washington State's Department of Occupational Safety and Health (DOSH) of the death of a 38-year-old orchard worker.

After reviewing the DOSH investigation report, WA FACE investigators interviewed the managing partner and orchard manager. The managing partner provided information regarding the history, organization, and the health and safety programs of the company, as well as insight into the surrounding incident. The managing partner and orchard manager provided details regarding the grader involved in the incident and common work practices. During the course of the investigation, the WA FACE investigation team reviewed police reports, the coroner's report, and DOSH investigation documents and photographs.

\section{Employer}

The employer has been in the fruit farming industry since 1982 and owns six orchards and grows mostly apples and cherries. Depending on the season, the employer has a range of approximately 400-900 employees working on the six orchards. Approximately 24-30 of these employees have the same job title and duties as the worker.

The worker's job title was tractor driver and irrigator. His job duties included operating tractors, moving and adjusting water flow for the irrigation of the orchard, and checking sprinklers to ensure that they were not damaged. The managing partner estimated that there were approximately 300 workers at the orchard at the time of the incident and that Spanish is the primary language for approximately $99 \%$ of all orchard employees.

\section{Employer Work Organization}

The organization of all six orchards consists of an orchard manager who oversees the orchard, crew leaders, and supervisors. Crew leaders are responsible for overseeing a crew of 20-25 workers who work in the orchard. Supervisors are responsible for overseeing the machinery operators. 


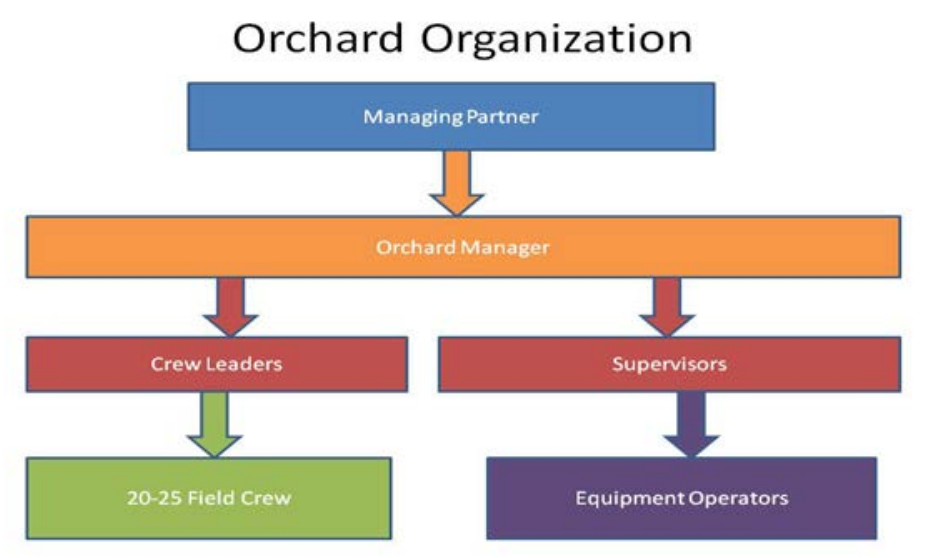

Diagram of the orchard organization system

\section{Employer Safety/Training Program}

Training programs were provided to workers verbally and in writing in both English and Spanish. Topics covered in the trainings included:

- Company policies

- Safety rules and personal protective equipment

- Emergency plans

- How to report injuries/accidents
- Chemical safety

- Lockout/tagout

- Hearing conservation

Training for machine operators included demonstrating the ability to properly operate the specific machinery they would be using. Machines used in the orchard included the motor grader, a backhoe, low profile orchard tractors, four wheel all-terrain vehicles (ATVs), and forklifts. The training for towing a vehicle up a road was done verbally by the operator or orchard manager and was not documented.

The employer held a monthly safety meeting with orchard managers, crew leaders, and supervisors. Afterwards, crew leaders and supervisors would meet with their workers to go over the topics of the safety meeting, as well as any other issue that their crew was having. The employer had an incentive program to promote safety. The incentive program rewarded crew leaders and supervisors with a \$25 gift card if their crew did not have an accident for the month.

The employer had requested 4 safety consultation visits from DOSH over the three years prior to the incident. One of the visits was a comprehensive safety consultation, although vehicle towing procedures was not reported as an item covered during the visit. 


\section{Worker}

The worker was born in Mexico and had been a full-time employee of the orchard for at least 7 years. At the time of the incident, the worker's job title was tractor driver and irrigator. According to the managing partner, the worker operated orchard machinery during the harvest season and worked on orchard maintenance during the rest of the year. The managing partner was uncertain if the worker had been a tractor driver and irrigator for his whole employment time. The worker's primary language was Spanish, and his ability to speak, write, or understand English was limited. According to the motor grader driver, the worker had assisted in the process of towing a vehicle at least 3-4 times before.

\section{Semi-truck Driver}

The semi-truck driver was not an employee of the orchard. He was employed by one of the partners of the employer. He was not provided training by his employer or by the worker's employer on the towing procedures.

\section{Operator of the Motor Grader}

The operator of the motor grader had been a full-time employee for the employer for at least 7 years and had been an operator of the motor grader since its purchase in 2003. He was considered an experience operator and also supervised other machinery operators. The operator was a certified trainer for machinery operation by the State of Washington Department of Agriculture and was responsible for providing training to other employees on how to operate machinery used in the orchard.

\section{Orchard and Gravel Road}

This orchard, located in Eastern Washington, is approximately 1,040 acres and has approximately 800 planted trees for the production of apples and had been in operation for approximately 7 years at the time of the incident. The road where the incident occurred is covered in packed gravel and has a slope of approximately $6-7 \%$, as determined by the DOSH inspector using a surveying instrument used to measure angle of inclination called a Leitz Abney level. On the day of the incident, the road was in good condition with no ice or mud and the weather was clear and sunny. 


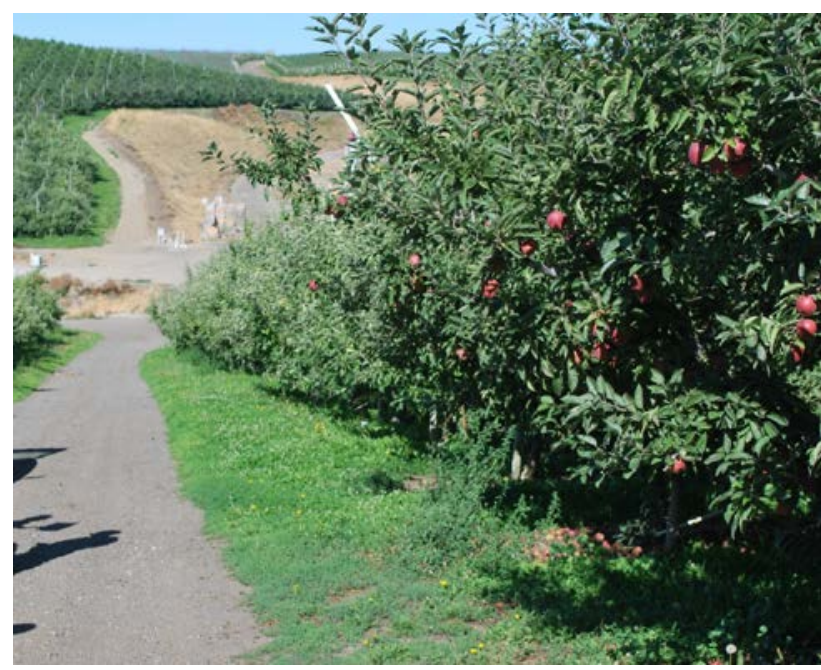

Orchard Road with 6-7\% grade.

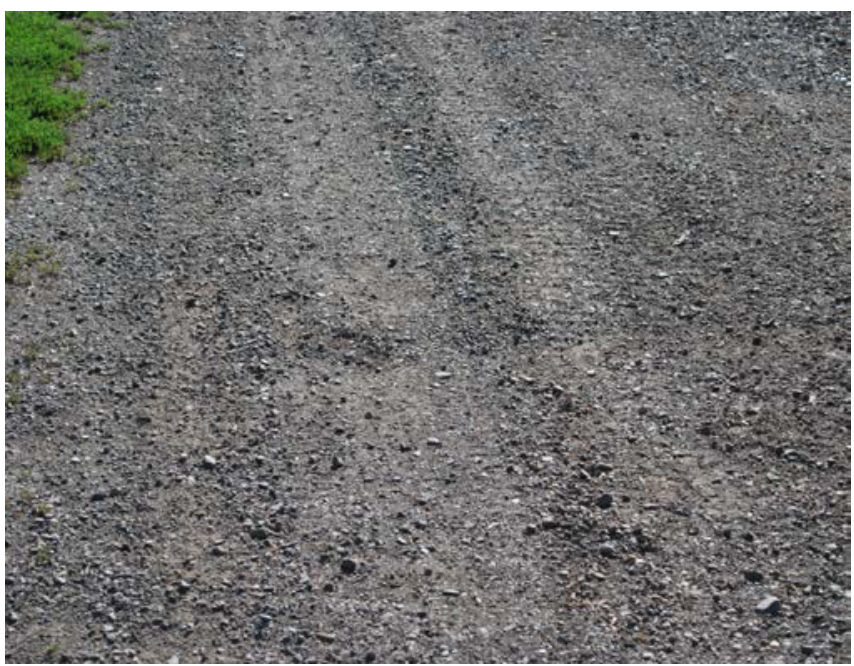

Close-up of gravel covering the orchard road.

\section{Semi-truck and flatbed trailer}

The semi-truck and flatbed trailer was at the orchard to pick up full apple bins. The semi-truck was traveling to a designated level area used for loading apple bins when it lost traction due to the $6-7 \%$ grade road and got stuck.

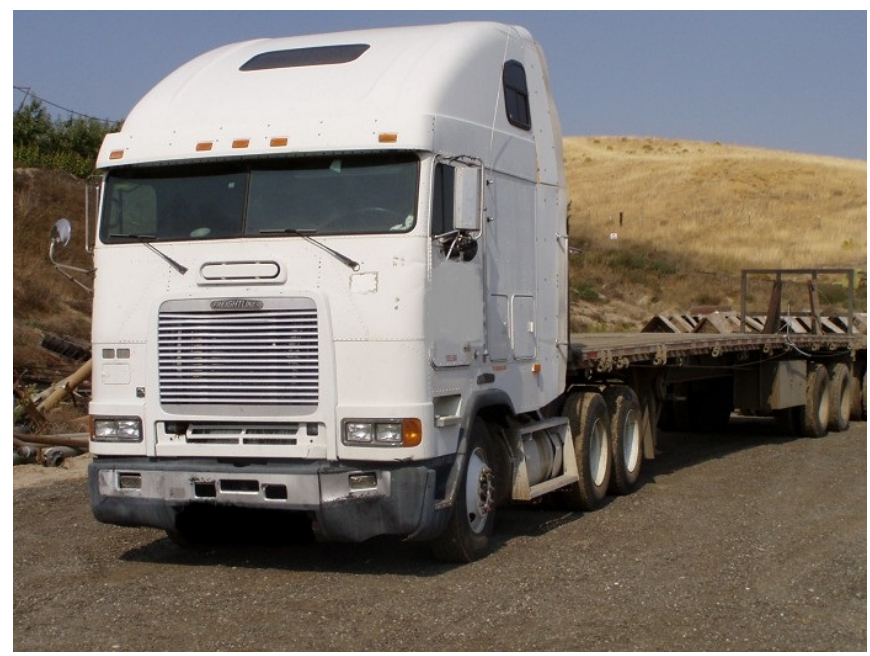

Semi-truck with flatbead trailer involved in incident.

The apple bins are 46" $\times 48$ " and weigh approximately 900 lbs when loaded with apples and are loaded onto the trailer by a forklift. When the truck is fully loaded with the apple bins it weighs approximately 105,000lbs. 


\section{Motor Grader}

The motor grader was a Wabco Power Flo model number 666BTGM6630 equipped with hydraulic brakes. The grader was purchased used and had been with the orchard since 2003. The motor grader was used to smooth the roads throughout the orchard and to tow vehicles that were unable to make it up any of the orchard roads. According to the safety manual, the motor grader was not equipped with any reverse warning system, but was equipped with a horn. According to the DOSH inspector, the horn was functioning properly at the time of the incident.

The motor grader does not have gears like an automobile to control its direction. According to the safety manual, the forward and reverse movement of the motor grader is operated by a pedal referred to as a "rocker pedal" by the managing partner. If the operator wants the motor grader to move forward the operator would push down on the toe end of the rocker pedal. If the operator wanted the grader to go in reverse, the operator would push down on the heel end of the rocker pedal. The motor grader also has an accelerator-decelerator pedal that controls its speed. To operator would release the pedal to accelerate and push down on the pedal to decelerate the motor grader.

Towing of the semi-truck was the motor grader's first activity that day. It is uncertain what the last date of use was for the motor grader, but the operator of the motor grader reported that it had not been used in a couple months. There are only three employees allowed to operate the motor grader; the orchard manager, the operator at the time of incident, and one other employee not involved in the incident.

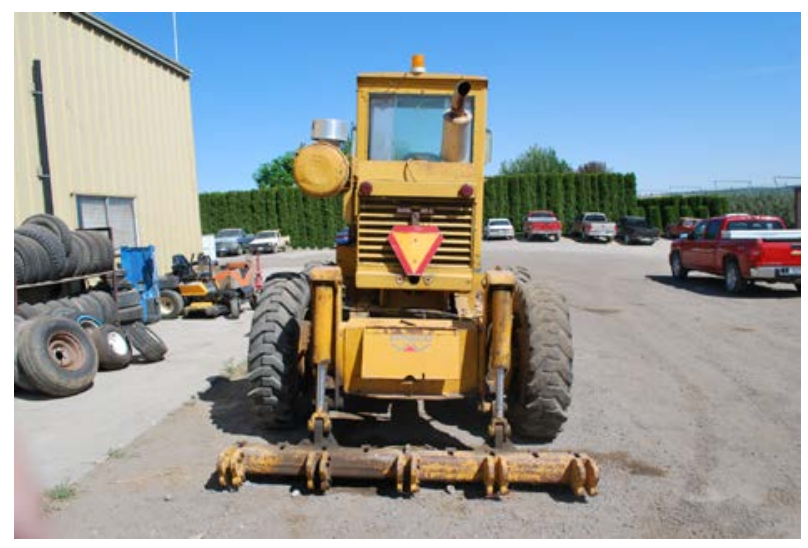

View of motor grader from rear.

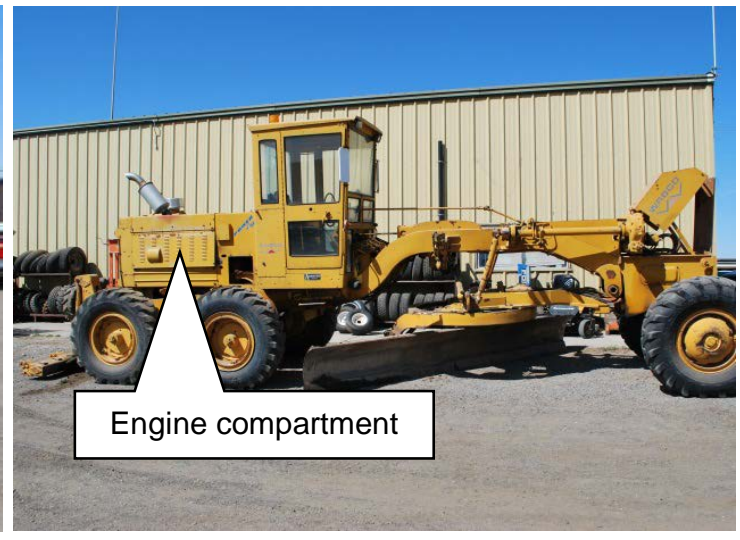

Side view of motor grader. 


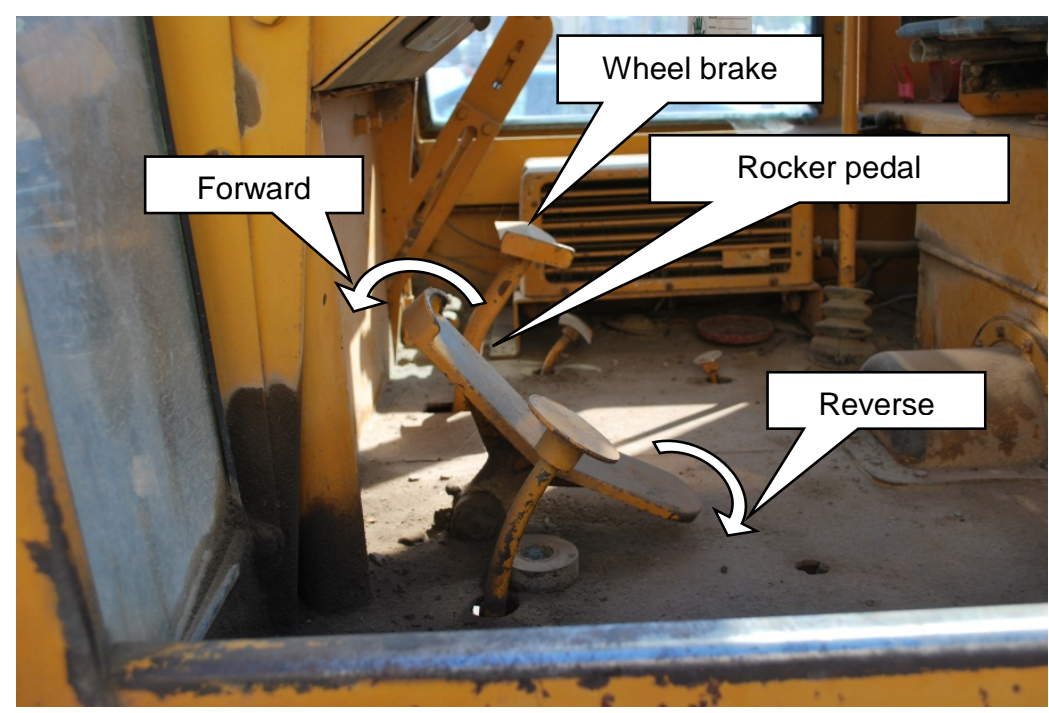

Rocker pedal and wheel brake.

\section{Motor Grader Brakes}

According to manufacturer's manual, each of the four tandem wheels on the motor grader is equipped with a hydraulic actuated, shoe-type brake. The brakes activate when the operator pushes down on the wheel brake located to the right of the rocker pedal. The operator of the grader at the time of the incident said that the brakes failed and he was unable to stop it as it was backing up. The operator said that the brakes often needed to be pumped before they would work completely after the grader had not been used for at least a week.

After the incident the DOSH inspector tested the traveling and emergency brakes of the motor grader on the orchard road where the incident occurred. The inspector did not find any brake fluid leaks, and both the traveling brakes and the emergency brakes prevented movement of the grader on the sloped road.

The employer conducted routine maintenance on the motor grader and according to the DOSH inspector the motor grader was in fair to good condition. The motor grader was inspected on a monthly basis by the orchard manager to ensure that all parts were properly functioning. The motor grader was not inspected before being used on the day of the incident. 


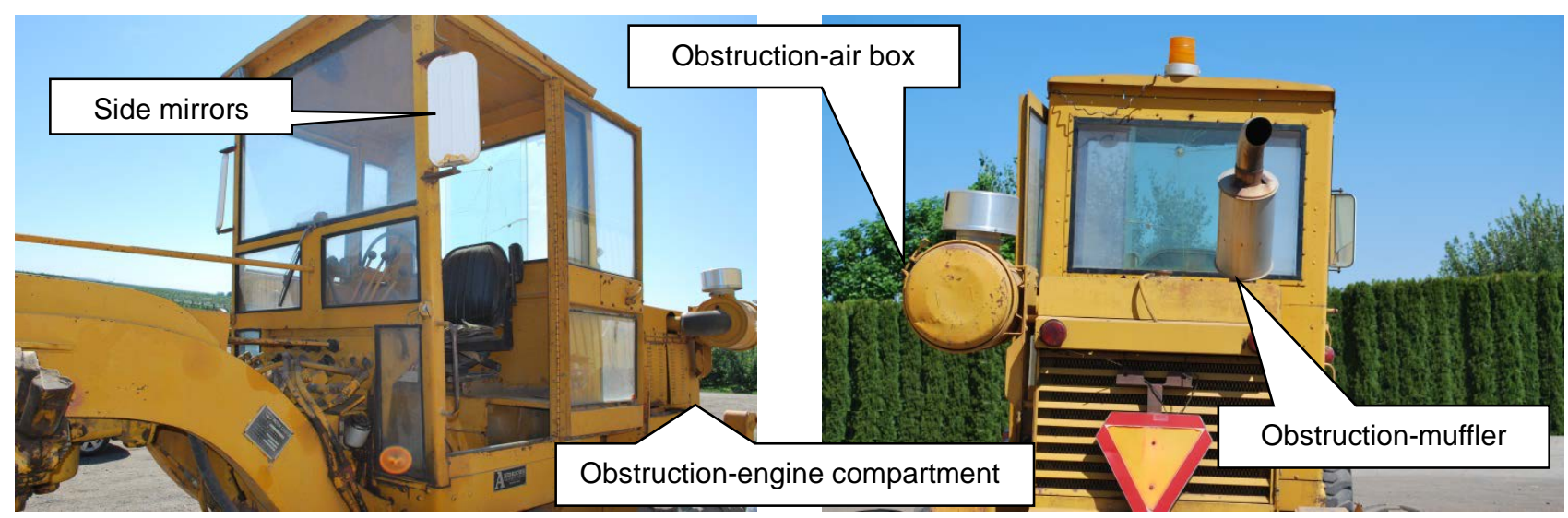

Side mirrors and back window (along with view obstructions) the motor grader operator would have used while reversing downhill.

\section{INVESTIGATION}

On September 27, 2009, a semi-truck with flatbed trailer arrived at the orchard to pick up full apple bins for transportation. The semi-truck was unable to maintain traction on the orchard gravel road due to the $6-7 \%$ grade and needed to be towed up the hill. The motor grader operator noticed that the semi-truck with flatbed trailer was stuck and asked the worker to get the chain from the back of a pick-up truck and meet him at the semi-truck. They were going to use the motor grader to tow the semi-truck up the road.

The worker, who had started work that day at 7 a.m., approximately 3 hours before the incident, retrieved the connecting chain and went down to the front of the stuck semitruck and started to attach the chain. The chain that the worker was attempting to connect to the semi-truck was between 7-10 feet long. According to the managing partner, this was too short for the task being performed.

The semi-truck driver watched the worker while leaning against the driver's side front bumper of the truck. He was explaining to the worker where to attach the chain to the semi-truck. He said that he felt responsible for the semi-truck and wanted to ensure that the towing didn't cause damage to any hoses or wires.

In the meantime, the operator retrieved the motor grader and started driving towards the semi-truck. It is uncertain if the operator started reversing downhill before or after the worker and the driver went to the front of the semi-truck to attach the chain. The operator reported that he could see them from the cab.

Prior to reversing downhill, the operator did not conduct any functional testing of the motor grader brakes or other systems. He said he pushed down on the brake pedal as he reversed downhill (approximately 40 feet from the semi-truck) and noticed that the 
brakes were not working. He tried pumping the brakes but the motor grader only slowed and did not stop. He also tried yelling at the worker and truck driver to move out of the way but was unable to be heard over the noise from the motor grader.

While the worker was bent over connecting the chain, the motor grader collided with the front of the semi-truck, crushing the worker. The semi-truck driver tried to jump out of the way but his right leg was pinned between the motor grader and the semi-truck.

The worker suffered fatal injuries to his lower torso while the semi-truck driver suffered a fracture to his right femur and pelvis. The motor grader operator activated the accident response protocols after getting off the motor grader. Accident protocols consisted of calling 911, someone going to the road to meet emergency crews, and providing first aide to the worker. Emergency medical services unsuccessfully attempted to revive the worker.

Based on the inspection of the motor grader cab done by the WA FACE program and the managing partner, it is likely that the operator of the motor grader would have to stand in the cab and look over his shoulder out the back window beyond the rear of the engine compartment in order to see the worker and semi-truck driver while reversing the motor grader down the sloped road.

Two eye witness reports claimed that the motor grader came to a complete brief stop about 7 feet away from the semi-truck before suddenly reversing into the semi-truck. This indicates that the brakes may have been functioning properly at the time of the incident.

\section{CONTRIBUTING FACTORS}

- Workers in the path of the motor grader.

- Failure to test the function of the motor grader brakes.

- Inadequate development of safe SOPs for towing vehicles.

- Lack of adequate training for workers involved in towing vehicles.

- Lack of audible reverse alarm to warn workers of the motor grader movement.

- Lack of system to alert operator of the presence of nearby workers.

\section{CAUSE OF DEATH}

The medical examiner listed the cause of death as blunt force trauma to lower torso. 


\section{RECOMMENDATIONS AND DISCUSSION}

\section{Recommendation 1: Employers should implement and enforce the use of job hazard analysis (JHA) tools and techniques to identify and eliminate hazards.}

\section{Discussion:}

If the worker and the driver of the semi-truck had recognized the hazard of being in the path of the reversing motor grader, they would not have been struck or crushed by the grader and their injuries would have been prevented.

The employer and workers might have recognized the hazards associated with this process by completing a job hazard analysis (JHA). A JHA is a process that looks at job tasks in order to identify their associated hazards and develop control strategies and techniques before injuries occur. ${ }^{1}$ In this case the JHA might have helped identify the hazard of being crushed between the motor grader and the stuck semi-truck and prompted the development of a safe vehicle towing procedure. Employers should always include workers in the JHA process to ensure a better analysis that will encourage workers to implement the identified control strategies.

For more information on JHA see www.osha.gov/Publications/osha3071.pdf

\section{Recommendation 2: Employers should create and enforce comprehensive SOPs for towing vehicles.}

\section{Discussion:}

Employers should develop comprehensive safe SOPs to control workers' exposures to potential life threatening hazards associated with towing vehicles. These SOPs should be created and documented in writing after completing a JHA to ensure that they address, abate, and control the hazards involved with towing vehicles. All employees and contractors who are involved in vehicle towing should be involved in the development and trained on the SOP to ensure that everyone is aware of the hazards and how to abate or control them.

All SOPs for using motor graders, especially ones without an audible alarm system, for towing vehicles should include a communication plan for when it is safe for workers to move into the path of the motor grader. The SOP should also include a technique, such as chock blocks, to prevent the motor grader from making unexpected movements.

The employer's post incident remediation is an example of an SOP for towing a vehicle. 


\section{Post-Incident Remediation}

Following the incident the employer created a written SOP for towing stuck vehicles. The new procedure involves a minimum of three and up to four participants; the motor grader operator, the person connecting the strap to the stuck vehicle and grader, a spotter, and a person to put wheel chocks behind the motor grader tires.

The SOP requires the person connecting the strap to wait near the stuck vehicle with the connecting strap but out of the path of the motor grader until it comes to a complete stop. The employer purchased a longer towing strap, 15-20 feet, in order to provide more room between vehicles and to more safely connect the motor grader and stuck vehicle.

Once the motor grader comes to a complete stop, chock blocks are put behind the tires by a worker or the spotter to prevent the motor grader from backing into the stuck vehicle. After the chock blocks are put in place, the spotter signals the worker that it is safe to attach the towing strap to the truck and motor grader. After the strap is attached, and no workers are between the motor grader and stuck vehicle, the chock blocks are removed and the motor grader tows the stuck vehicle. At no time is a worker permitted to be positioned between the motor grader and the stuck vehicle while the motor grader is in motion.

\section{Recommendation 3: Employers should ensure that all heavy mobile machinery is equipped with functioning safety systems and alarms.}

\section{Discussion:}

According the National Safety Council all motor graders, bulldozers, and scrapers should be equipped with an audible reverse alarm that operates automatically when the machinery is in reverse motion. ${ }^{3}$ The incident motor grader was not equipped with a reverse alarm. If it had a reverse alarm, the worker and semi-truck driver might have been less likely to remain in the crush hazard area. If heavy mobile machinery was manufactured without a reverse alarm it is recommended that employers either remove that piece of machinery from service, or have it retrofitted with a reverse alarm.

Warning lights that operate automatically when the machine is moving in reverse are another device that could potentially alert workers of hazards. If the motor grader had warning lights to alert the worker and the truck driver, they might have been less likely to enter or remain in the crush hazard area between the vehicles. 
An alternative to backup alarms or lights that might have been effective in this situation is a spotter. Spotters are actually required in addition to audible reverse alarms in some construction situations. A spotter could have alerted the operator that the worker and the driver were behind the machinery and signaled when it was safe to back up. In the case of a brake failure, a spotter could have warned the worker and the driver to get out of the path of the motor grader.

This motor grader was equipped with side mirrors. However, it still had blind spots for the operator. The height and length of the engine compartment created blind spots behind the machine that obscured the operator's view of the area where the worker and the driver were attempting to connect the chain. Diagrams 2 and 3, in appendix A, show examples of a motor grader operator's blind spots from the ground level and five feet above the ground (These blind spots were determined using a 27 ton CAT16G motor grader). ${ }^{4}$ For more diagrams characterizing machinery visibility for motor graders and other commonly used heavy machinery see NIOSH's Construction Machinery Visibility webpage at: www.cdc.gov/niosh/topics/highwayworkzones/BAD/imagelookup.html

\section{Recommendation 4: All operators of heavy machinery should perform a safety inspection before operating machinery. Inspections should include functional testing of safety devices.}

\section{Discussion:}

The operator reported that the motor grader had not been used in a couple months. Before using the motor grader, he did a quick walk around inspection but it did not include any functional testing of the hydraulic brakes and other safety systems. The operator also reported it was common for the motor grader to need the brake pedal pumped to work when it had not been used recently. If the brakes had been functionally tested, the operator could have identified and addressed any problems with the brakes before reversing the motor grader down a sloped road.

Additionally, designers and manufacturers of motor graders and other heavy machinery should:

Recommendation 5: Design and manufacture motor graders with safety features that notify the operator that there are workers near or in the path of the motor grader. 


\section{Discussion:}

During operation, motor graders frequently move and change directions near workers on foot. Therefore, it is recommended that manufacturers install proximity detection equipment. Proximity detection equipment uses methods such as global positioning systems (GPS), lasers, sonic technology, and cameras to alert operators of workers near the machinery and help prevent crushing and run-over incidents.

Research relevant to motor graders conducted by NIOSH found that operators of heavy highway machinery, such as dump trucks, preferred systems that alerted them of nearby hazards paired with cameras that provide visibility in blind spots. ${ }^{5}$

\section{ACKNOWLEDGEMENTS:}

This report was reviewed by stakeholders from labor and business communities and various Washington State and federal worker safety agencies. Though we are unable to acknowledge specific individuals for their contributions to this report, we would like to recognize the following for their help and support of the FACE mission and objectives:

- $\quad$ The Employer's representatives.

- $\quad$ Division of Occupation Safety and Health (DOSH) Compliance Operations.

- $\quad$ Federal FACE Program Management (NIOSH).

- $\quad$ Safety \& Health Assessment \& Research for Prevention (SHARP).

- Washington State Attorney General's Office. 
APPENDIX A:

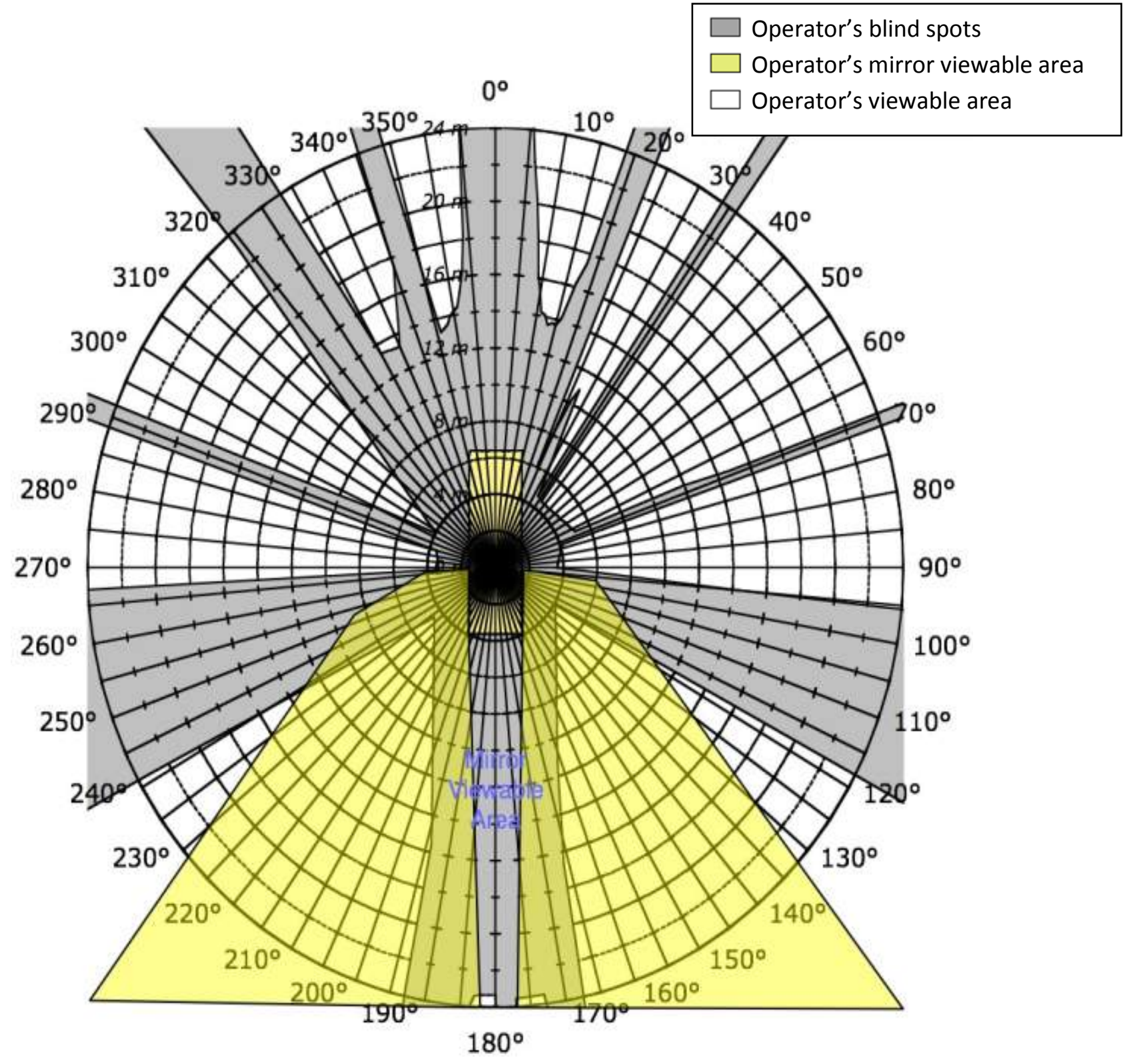

Diagram 2: Blind spots at ground level for a 27 ton CAT16G Motor Grader 


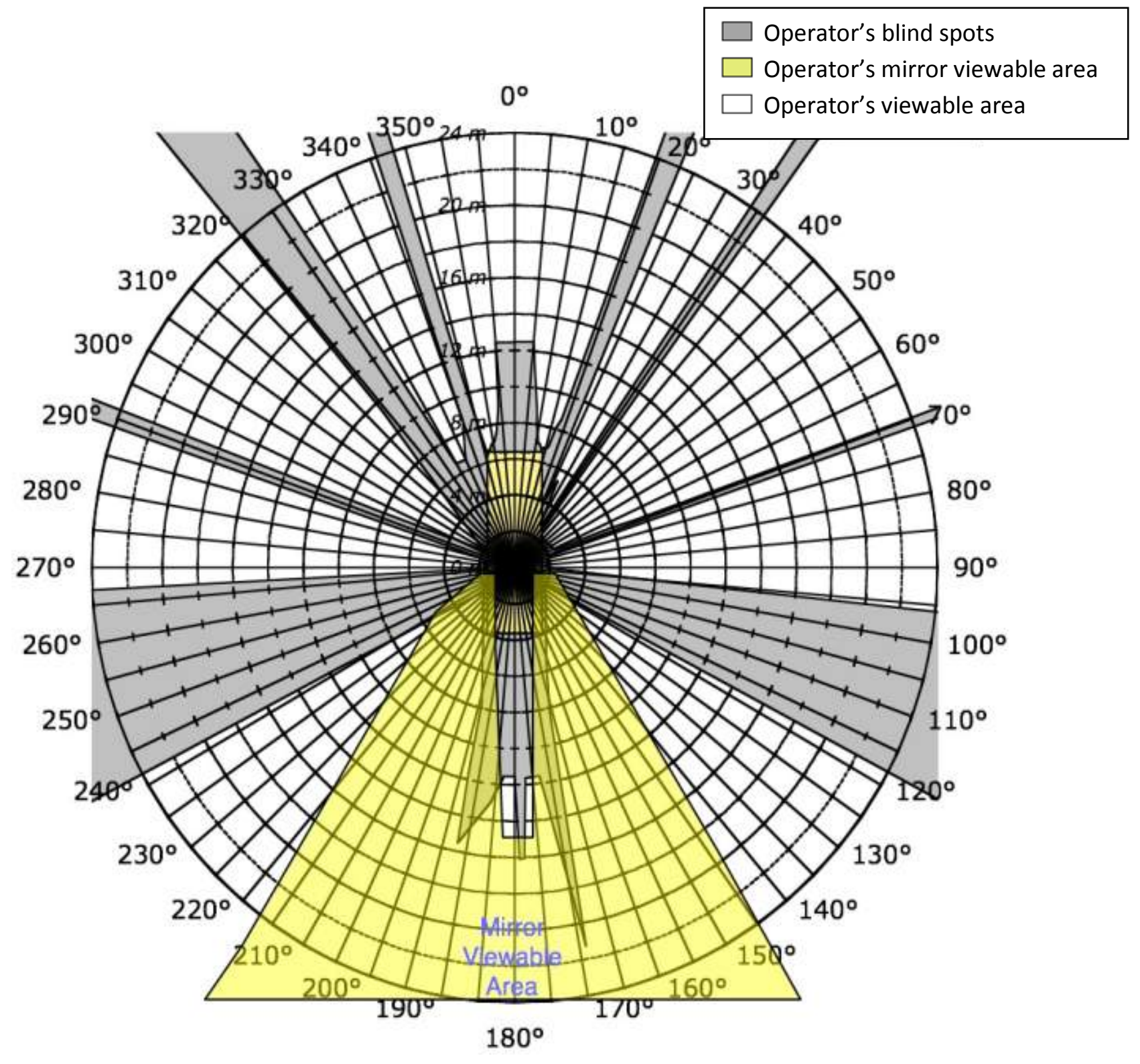

Diagram 3: Blind Spots at five feet above ground level for a 27 ton CAT16G Motor Grader 


\section{Job Hazard Assessment}

Company Name:

Prepared by:

This is a sample entry for a common task to illustrate how the template can be used to characterize hazards. Apply this technique to your business and continue to identify hazards and fill-in the table.

\begin{tabular}{|c|c|c|c|c|c|c|}
\hline $\begin{array}{l}\text { What are the } \\
\text { hazards }\end{array}$ & $\begin{array}{l}\text { Who might } \\
\text { be harmed } \\
\text { and how? }\end{array}$ & $\begin{array}{l}\text { What are } \\
\text { you already } \\
\text { doing? }\end{array}$ & $\begin{array}{l}\text { What further } \\
\text { action is } \\
\text { necessary? }\end{array}$ & $\begin{array}{l}\text { Action by } \\
\text { whom? }\end{array}$ & $\begin{array}{l}\text { Action } \\
\text { by } \\
\text { when? }\end{array}$ & $\begin{array}{l}\text { Date } \\
\text { completed? }\end{array}$ \\
\hline $\begin{array}{l}\text { Slips, trips } \\
\text { and falls }\end{array}$ & $\begin{array}{l}\text { Staff and } \\
\text { others may } \\
\text { be injured } \\
\text { if they trip } \\
\text { over } \\
\text { objects or } \\
\text { slip on } \\
\text { spills. }\end{array}$ & $\begin{array}{l}\text { General } \\
\text { good } \\
\text { housekeepi } \\
\text { ng. Areas } \\
\text { well lit. No } \\
\text { hoses or } \\
\text { cables } \\
\text { without } \\
\text { warnings. } \\
\text { Staff keeps } \\
\text { locations } \\
\text { clean and } \\
\text { clear of } \\
\text { debris. }\end{array}$ & $\begin{array}{l}\text { Better, more } \\
\text { timely } \\
\text { housekeeping } \\
\text { on spills }\end{array}$ & $\begin{array}{l}\text { All staff, } \\
\text { supervisors } \\
\text { to monitor. }\end{array}$ & $\begin{array}{l}\text { Starting } \\
\text { now, } \\
\text { review } \\
\text { in } 1 \\
\text { month }\end{array}$ & \\
\hline & & & & & & \\
\hline & & & & & & \\
\hline & & & & & & \\
\hline & & & & & & \\
\hline
\end{tabular}

- $\quad$ Adapted from Health and Safety Executive. ${ }^{6}$ 


\section{REFERENCES}

1. Administration, OSHA. (2002 ). Job Hazard Analysis. USDOL, U.S. Department of Labor.

2. U.S. Army Core of Engineers (1997). Safety Checklist for Scrapers, Motor Graders, and Other mobile Equipment. SAD Form 1666f-R.

3. National Safety Council. (1985). Motor Graders, Bulldozers, and Scrapers, National Safety Council: 7.

4. U.S. Mine Rescue Association. Blind Spots Study: Large Mining Equipment. Retrieved from: http://bit.ly/wdzUhp. Retrieved on: March 12, 2012.

5. Ruff, T. M. (2004). Evaluation of Devices to Prevent Construction Equipment Backing Incidents. Safety Research Laboratory. Spokane, National Institute of Occupational Safety and Health: 1 - 10.

6. Health and Safety Executive. Five Steps to Risk Assessment. Retrieved from: http://bit.ly/5ejn2x. Retrieved on: March 5, 2012. 


\section{INVESTIGATOR INFORMATION}

Todd Schoonover has a PhD in Industrial Hygiene from the University of Illinois at Chicago. He is a Certified Industrial Hygienist $(\mathrm{CIH})$ and Certified Safety Professional (CSP). Todd is currently the Principal Investigator for the WA FACE program.

Eric Jalonen has a MPH from East Carolina University. He is a Research Investigator with the WA FACE program.

Randy Clark has a BA from The Evergreen State College. He is a Research Analyst with the WA FACE program.

\section{Washington State FACE Program Information}

The Washington State Fatality Assessment and Control (WA FACE) program is one of many workplace health and safety programs administered by the Washington State Department of Labor \& Industries' Safety \& Health \& Research for Prevention (SHARP) program. It is a research program designed to identify and study fatal occupational injuries. Under a cooperative agreement with the National Institute for Occupational Safety and Health (NIOSH), WA FACE collects information on occupational fatalities in WA State and targets specific types of fatalities for evaluation. WA FACE investigators evaluate information from multiple sources. Findings are summarized in narrative reports that include recommendations for preventing similar events in the future. These recommendations are distributed to employers, workers, and other organizations interested in promoting workplace safety. NIOSH-funded, state-based FACE programs include: California, lowa, Kentucky, Massachusetts, Michigan, New Jersey, New York, Oregon, and Washington. WA FACE does not determine fault or legal liability associated with a fatal incident. Names of employers, workers and/or witnesses are not included in written investigative reports or other databases to protect the confidentiality of those who voluntarily participate in the program.

Additional information regarding the WA FACE program can be obtained from:

Washington State FACE Program

www.Ini.wa.gov/Safety/Research/FACE/default.asp

PO Box 44330

Olympia, WA 98504-4330

1-888-667-4277

References: 